\title{
STUDI JENIS VEGETASI PAKAN BEKANTAN (Nasalis larvatus, Wurmb) DI KAWASAN TAMAN NASIONAL DANAU SENTARUM KAPUAS HULU KALIMANTAN BARAT
}

(Study The Type Of Vegetation To Feed The Proboscis Monkey (Nasalis larvarus, Wurmb) In The National Park Lake Sentarum Kapuas Hulu West Borneo)

\author{
Restu Anda, Erianto, Hari Prayogo \\ Fakultas Kehutanan Universitas Tanjungpura Pontianak. Jl. Daya Nasional Pontianak 78124 \\ Email : restuanda7@gmail.com
}

Abstract

Proboscis Monkey is a kind of primate which is found in Indonesia, especially in Borneo Island (endemic) it is protected from colonialsm. They can be survived in the abundant natural resources. This research uses track combination methode with plotted area in purposive sampling on the bekantan found. Base on the result of the research is found 20 kinds of plants from 14 families 8 kinds of them is plants that eaten: Kawi (Shorea balangeran), Kebesi (Memecylon edule), Putat (Barringtonia acutangula), Sikup (Garcinia celebica), Temirit (Timonius flavescens) Kayu Tahun (Carallia sp), Mentangis (Ixora mentangis) dan Rengas (Gluta renghas), it is obtain that shoots, leaves is most likely eaten by it from the result of data analysis poles $(\bar{H}=0,82)$ is found the highest plant diversity index, it is followed sapling $(\bar{H}=$ $0,77)$, trees $(\bar{H}=0,67)$, seeding $(\bar{H}=0.61)$. From the repapitulation of abundance plants of species is uneven.

Keyword: Bekantan, Feed source of bekantan and Vegetation.

\section{PENDAHULUAN}

Satwa liar adalah semua binatang yang hidup di darat dan di air maupun di udara yang masih mempunyai sifat-sifat liar, baik yang hidup bebas maupun yang dipelihara oleh manusia (Dephut, 1990). Bekantan (Nasalis larvatus) merupakan salah satu jenis primata yang hanya bisa ditemukan di Indonesia khususnya di Pulau Kalimantan (Endemic) yang keberadaannya dilindungi semenjak zaman kolonial Belanda yaitu pada tahun 1931 melalui Dierenbeschermings ordonantie (UU Perlindungan Binatang Liar : Staatblad tahun 1931 No. 134) dan Dierenbeschermings Verordening (Peraturan Perlindungan Binatang Liar tahun 1931 dan tahun 1935), UU No. 5
Tahun 1990, Surat Keputusan Menteri Kehutanan No. 301/Kpts-II/1991 (10 Juni 1991), Surat Keputusan Menteri Kehutanan No. 882/Kpts-II/1992 (8 September 1992), dan diperkuat dengan Peraturan Pemerintah No. 7 Tahun 1999 mengenai satwa dan tumbuhan yang dilarang untuk dipergunakan secara umum, baik untuk diperdagangkan maupun dimanfaatkan tanpa izin.

Dalam mempertahankan kelangsungan hidup di alam bebas, bekantan membutuhkan ketersediaan pakan yang berlimpah agar dapat mempertahankan kelestariannya. Bekantan merupakan satwa yang hidup berkelompok, jika pakan tidak tersedia atau kurang dari jumlah yang dibutuhkan, 
kemungkinan dapat terjadi perpindahan untuk mencari daerah baru yang pakannya tersedia dalam jumlah banyak. Apabila tempat untuk berpindah tidak memungkinkan karena beberapa sebab, terpaksa bekantan akan memakan makanan yang ketersediaannya terbatas di lokasi tersebut. Hal ini akan menimbulkan beberapa akibat yaitu; menurunnya kondisi kesehatan, kelaparan yang dapat menyebabkan kematian, penurunan populasi, bahkan dapat menyebabkan kepunahan. Bismark (2009) berpendapat bahwa komposisi dan jenis pakan bekantan pada setiap tipe habitat berbedabeda. Bekantan memilih sumber pakannya sesuai dengan nutrisi yang dibutuhkan oleh tubuhnya. Tumbuhan pakan bekantan relatif mengandung protein yang tinggi dan rendah serat, serta secara signifikan kandungan fosfor dan potassium lebih tinggi dibandingkan tumbuhan yang tidak dimakan bekantan di habitatnya.

Taman Nasional Danau Sentarum (TNDS) merupakan habitat bagi berbagai jenis mamalia, sebagian besar jenis mamalia yang ada di kawasan ini merupakan jenis endemik. Salah satu diantaranya ialah bekantan (Nasalis larvatus) yang kini dalam kondisi terancam atau diambang kepunahan karena habitatnya menyempit akibat aktivitas manusia seperti illegal logging, pemburuan liar dan kebakaran hutan di dalam maupun di sekitar TNDS. TNDS merupakan kawasan yang rawan terhadap kebakaran hutan. Maka dari itu, hampir setiap tahun terjadi kebakaran hutan di kawasan TNDS yang dipicu oleh aktivitas manusia dan mengakibatkan rusaknya habitat para satwa. Untuk mempertahankan kelangsungan hidupnya satwa liar membutuhkan keseimbangan ekosistem, kerusakan lingkungan habitat menyebabkan potensi vegetasi sebagai bahan pakan dari bekantan tersebut berkurang, sedangkan hutan tersebut merupakan habitat dari bekantan. Hal ini menimbulkan dampak negatif terhadap kelestarian dan mengakibatkan keberadaannya di alam terancam punah. Sebagai salah satu upaya untuk menjaga kelestarian bekantan di TNDS, maka perlu adanya penelitian mengenai potensi tegakan yang menjadi sumber pakan yang tersedia bagi bekantan di TNDS. Tujuan dilakukannya penelitian ini yaitu untuk memperoleh data jenis dan potensi vegetasi yang merupakan sumber pakan bekantan (Nasalis larvatus, Wurmb) di sekitar Resort Semangit kawasan TNDS Kapuas Hulu. Manfaat dari penelitian ini diharapkan dapat memberikan informasi dan sebagai bahan masukan untuk mengetahui jenis dan potensi vegetasi yang merupakan sumber pakan bekantan (Nasalis larvatus, Wurmb) sehingga dapat dijadikan data bagi pengelolaan dan pelestarian bekantan di Resort Semangit kawasan TNDS.

\section{METODE PENELITIAN}

Penelitian ini dilaksanakan di Resort Semangit kawasan Taman Nasional Danau Sentarum Kabupaten Kapuas Hulu Kalimantan Barat, dengan lama waktu penelitian \pm 4 minggu (16 Mei-16 Juni 2018). Peralatan yang digunakan antara lain: teropong, kamera digital, GPS, peta lokasi, kompas, kalkulator, meteran, tali, alat tebas, phi band, buku identifikasi jenis 
tumbuhan, sampan/perahu, tally sheet pengamatan dan alat pembuatan herbarium. Objek penelitian ini adalah jenis pakan satwa liar Bekantan (Nasalis larvatus, Wurmb) yang ditemukan pada jalur-jalur pengamatan di sekitar Resort Semangit dalam kawasan TNDS. Penelitian ini menggunakan metode kombinasi jalur dengan garis berpetak yang diletakkan secara sengaja (purposive) pada lokasi ditemukan bekantan. Jalur pengamatan dibuat mulai dari pinggir sungai (yang bervegetasi) ke arah dalam hutan. Dalam penelitian ini dibuat sebanyak 6 jalur pengamatan yang ditentukan secara sengaja (tempat ditemukannya bekantan) dengan jarak antar jalur masing-masing 50 meter. Lebar jalur pengamatan 20 meter, panjang ratarata 300 meter, dengan petak pengamatan berjumlah 15 petak.

\section{HASIL DAN PEMBAHASAN}

Jenis dan Bagian Tumbuhan yang Dimakan Bekantan (Nasalis larvatus)

Berdasarkan hasil penelitian di lapangan ditemukan 20 jenis tumbuhan dari 14 famili yang tercantum pada tabel 1 . Setelah dilakukan pengamatan didapatkan
8 jenis jenis tumbuhan yang dimakan bekantan di Resort Semangit kawasan TNDS yaitu : Kawi (Shorea balangeran), Kebesi (Memecylon edule), Putat (Barringtonia acutangula), Sikup (Garcinia celebica), Temirit (Timonius flavescens) Kayu Tahun (Carallia sp), Mentangis (Ixora mentangis) dan Rengas (Gluta renghas) yang disajikan pada tabel 2. Dari hasil pengamatan, diperoleh bahwa bagian yang paling banyak dimakan oleh bekantan adalah daun muda atau pucuk, kemudian disusul dengan bagian daun tua. Seperti yang dikemukakan oleh Zainudin dan Rezeki A (2016) bagian daun muda atau pucuk merupakan bagian yang paling disukai oleh para bekantan, hal ini dikarenakan pada bagian daun muda atau pucuk mengandung protein yang lebih banyak dibanding pada bagian lainnya. Bekantan merupakan primata arboreal yang memiliki kebutuhan protein dua kali lipat lebih banyak dari ukuran tubuhnya. Selain itu, tingginya tingkat makan terhadap daun disebabkan produksi buah dan bunga yang tidak selalu ada (musiman) (Atmoko dan Sadiyasa 2015). 
Tabel 1. Jenis-jenis Tumbuhan yang Terdapat Pada Lokasi Makan Bekantan (Nasalis larvatus) di Resort Semangit kawasan Taman Nasional Danau Sentarum (Table 1. These Kinds Of Plants On The Proboscis Monkey (Nasalis larvatus) Food Location In The Resort Semangit National Park Lake Sentarum)

\begin{tabular}{|c|c|c|c|}
\hline No & Famili & Nama Ilmiah & Nama Lokal \\
\hline 1. & Anacardiaceae & Gluta renghas & Rengas* \\
\hline 2. & Clusiaceae & Garcinia celebica & Sikup* \\
\hline 3. & Dipterocarpaceae & Dryobalanops rappa & Kelansau \\
\hline 4. & Dipterocarpaceae & Shorea balangeran & Kawi* \\
\hline 5. & Ebenaceae & Diospyros coriacea & Kenarin \\
\hline 6. & Ebenaceae & Ficus microcarpa & Jabai \\
\hline 7. & Euphorbiaceae & Croton $s p$ & Melayak \\
\hline 8. & Fabaceae & Crudia teysmannia & Timba Tawang \\
\hline 9. & Lecythidaceae & Barringtonia acutangula & Putat* \\
\hline 10. & Lythraseae & Lagerstroemia speciosa & Bungur \\
\hline 11. & Melastomataceae & Memecylon edule & Kebesi* \\
\hline 12. & Myrtaceae & Syzygium cauliflora & Emasung \\
\hline 13. & Myrtaceae & Syzygium inophyllum & Samak \\
\hline 14. & Polygalaceae & Xanthophyllum affine & Engkurung \\
\hline 15. & Rhizophoraceae & Carallia sp & Kayu Tahun* \\
\hline 16. & Rubiaceae & Fragraea fragrans & Tembesuk \\
\hline 17. & Rubiaceae & Ixora mentangis & Mentangis* \\
\hline 18. & Rubiaceae & Timonius flavescens & Temirit* \\
\hline 19. & - & - & Jijap \\
\hline 20. & - & - & Ringin \\
\hline
\end{tabular}

Keterangan: * : Tumbuhan yang dimakan bekantan

Tabel 2. Jenis dan Bagian-bagian yang Menjadi Makanan Bekantan (Table 2. The Types and Portion Of Proboscis Monkey (Nasalis larvatus) Food)

\begin{tabular}{|c|c|c|c|c|c|c|}
\hline \multirow{2}{*}{ No } & \multirow{2}{*}{ Jenis } & \multicolumn{4}{|c|}{ Bagian Yang Dimakan } & \multirow{2}{*}{ Keterangan } \\
\hline & & Pucuk & Bunga & Buah & Daun & \\
\hline 1. & Barringtonia acutangula & & & & & =dimakan \\
\hline 2. & Carallia sp. & & & & & \\
\hline 3. & Garcinia celebica & & & & & \\
\hline 4. & Gluta renghas & & & & & \\
\hline 5. & Ixora mentangis & & & & & \\
\hline 6. & Memecylon edule & & & & & \\
\hline 7. & Shorea balangeran & & & & & \\
\hline 8. & Timonius flavescens & & & & & \\
\hline
\end{tabular}
menjadi sumber pakan bekantan di Resort Semangit kawasan TNDS tersebut yaitu:

1. Kawi (Shorea balangeran)

Dari kedelapan jenis tumbuhan yang dikonsumsi oleh bekantan, indeks nilai penting tertinggi pada tingkat pohon yaitu kawi, hal ini disebabkan memiliki sebaran paling banyak (dominan) (Tabel 3). Bekantan menyukai pohon dengan tajuk yang besar dan beranting, selain tingkat sebarannya yang tinggi, pohon kawi merupakan tempat tidur (habitat) para bekantan. Potensi tingkat sebaran pohon kawi yang tinggi maka hal ini 
mendukung aktivitas makan dan sumber pakan bekantan (Gambar 1).

2. Kebesi (Memecylon edule)

M. edule merupakan genus anggota famili Melastomataceae (Widodo, 2015) yang memiliki helaian daun berbentuk bulat telur dengan tepian daun merata dan ujung yang meruncing. Disepanjang sungai pada lokasi penelitian yaitu Resort Semangit $M$. edule memiliki sebaran yang cukup banyak. Bagian dari $M$. edule yang dimakan oleh bekantan ialah bagian pucuk (daun muda) dan daunnya (Gambar 2).

3. Putat (Barringtonia acutangula)

Putat (B. Acutangula) terdapat disepanjang danau dan sangat dominan dibandingkan dengan jenis lainnya. Karena tumbuhan ini banyak ditemukan di tepian sungai dan danau yang merupakan habitat tempat makan bekantan. B. acutangula merupakan sumber pakan utama bekantan di TNDS, selain daun bagian lain seperti bunga dan buah juga menjadi sumber pakan bekantan. Pada saat musim bunga maka bunganya yang akan di makan oleh bekantan, begitu juga pada musim buah, maka dari itu pohon ini menjadi pakan utama bekantan di kawasan TNDS (Syukur, 2016) (Gambar 3).

\section{Sikup (Garcinia celebica)}

Lailati, (2017) melaporkan bahwa terdapat 64 jenis Garcinia yang tersebar di Indonesia, Garcinia umumnya ditemukan tumbuh dari dataran rendah sampai dataran tinggi (pegunungan). Khususnya $G$. celebica yang ditemukan pada lokasi penelitian sebagian besar (hampir semua) tumbuh pada daerah yang tergenang air, dengan tinggi pohon sekitar $14 \mathrm{~m}$ dengan batang berbentuk silindris jika diraba permukaan batangnya halus. Menurut pengakuan warga setempat pohon G. celebica juga dikenal sebagai buah manggis hutan, selain itu buah dari pohon G. celebica juga dimakan oleh bekantan pada saat musim buah (Gambar 4).

5. Temirit (Timonius flavescens)

T. flavescens anggota dari famili Rubiaceae yang banyak ditemukan disepanjang sungai pada lokasi penelitian, $T$. flavescens umumnya tumbuh pada derah dataran rendah maupun hutan rawa, mampu tumbuh hingga mencapai 10-15m dengan batang berbentuk silindris, bercabang, permukaan batang halus. Daunnya berbentuk lanceloate dengan ujung daun meruncing dan tepi daun rata. $T$. flavescens (Murti 2010).

6. Kayu Tahun (Carallia sp)

Carallia sp merupakan tumbuhan dari famili Rhizophoraceae yang umumnya tumbuh di hutan dataran rendah, terutama disepanjang sungai (Murti 2010). Kayu Tahun dapat tumbuh mencapai 10-14 m dengan batang lurus berbentuk silindris dan kulit batang halus. Daunnya berbentuk bulat telur terbalik dengan ujung daun yang meruncing. Kayu Tahun memiliki buah dan bunga yang akan tumbuh sesuai dengan musimnya.

7. Mentangis (Ixora mentangis)

I. mentangis merupakan tumbuhan dari famili Rubiaceae yang umumnya tumbuh dan dapat di jumpai pada hutan 
rawa yang tergenang (Usha et al. 2010). I. mentangis dapat tumbuh 5-8 m, memiliki daun berbentuk elliptic dengan susunan daun berkarang atau roset (whorls).

8. Rengas (Gluta renghas)

Tumbuhan dari famili Anacardiadiaceae ini merupakan tumbuhan yang secara periodik tergenang air tawar, di pinggir sungai, di atas tanah pasir dan tanah liat pada ketinggian sampai 300 meter di atas permukaan laut (dpl). Pohon $G$. renghas dapat tumbuh mencapai $30 \mathrm{~m}$, panjang batang bebas cabang 10-20 m, diameter dapat mencapai $>60 \mathrm{~cm}$. Berbatang lurus dengan tinggi banir dapat mencapai $2 \mathrm{~m}$, memiliki kulit luat berwarna merah-coklat dan mengeluarkan getah berwarna hitam. Daun berbentuk lanceolate atau lanset dengan susunan daunnya selang-seling (alternate) (Hanggari, 2008).

\section{Indeks Nilai Penting (INP) Vegetasi di Lokasi Penelitian}

INP dari 20 jenis tumbuhan yang ditemukan di lapangan disajikan pada tabel 4 .

Tabel 3. Jenis dan Kelimpahan Tumbuhan yang Terdapat Pada Lokasi Makan Bekantan (Nasalis larvatus) di Resort Semangit Kawasan Taman Nasional Danau Sentarum (Table 3. The Kinds and The Abundance Plants at The Proboscis Monkey (Nasalis larvatus) Food Location In The Resort Semangit National Park Lake Sentarum)

\begin{tabular}{lllrrrr}
\hline \multirow{2}{*}{ No } & \multirow{2}{*}{ Nama Ilmiah } & \multirow{2}{*}{ Nama Lokal } & \multicolumn{4}{c}{ INP } \\
\cline { 3 - 6 } & & Pohon & Tiang & Pancang & Semai \\
\hline 1. & Barringtonia acutangula & Putat* & 27,83 & 17,45 & 38,95 & 9,64 \\
2. & Carallia sp & Kayu Tahun* & 15,37 & 20,83 & 21,81 & 12,28 \\
3. & Croton sp & Melayak & 6,29 & - & - & - \\
4. & Crudia teysmannia & Timba Tawang & 0,95 & 1,26 & - & 1,75 \\
5. & Diospyros coriacea & Kenarin & 1,94 & - & - & 0,87 \\
6. & Dryobalanops rappa & Kelansau & 10,35 & 18,39 & 11,06 & 5,26 \\
7. & Ficus microcarpa & Jabai & 2,18 & 1,26 & - & 2,63 \\
8. & Fragraea fragrans & Tembesuk & 41,58 & 42,43 & 45,05 & 28,07 \\
9. & Garcinia celebica & Sikup* & 16,36 & 30,05 & 17,03 & 5,26 \\
10. & Gluta renghas & Rengas* & 17,57 & 20,68 & 11,11 & 16,66 \\
11. & Ixora mentangis & Mentangis* & 9,13 & 18,28 & 19,87 & 3,50 \\
12. & Lagerstroemia speciosa & Bungur & 7,97 & - & 2,05 & 0,87 \\
13. & Memecylon edule & Kebesi* & 6,52 & 21,75 & 15,90 & 4,38 \\
14. & Shorea balangeran & Kawi* & 113,97 & 73,51 & 95,67 & 91,23 \\
15. & Syzygium cauliflora & Emasung & 0,95 & 1,26 & - & 0,87 \\
16. & Syzygium inophyllum & Samak & 1,86 & 2,73 & 1,73 & - \\
17. & Timonius flavescens & Temirit* & 7,24 & 11,62 & 14,16 & 11,40 \\
18. & Xanthophyllum affine & Engkurung & 3,84 & - & 2,05 & 0,87 \\
19. & - & Jijap & 3,21 & 2,57 & - & - \\
20. & - & Ringin & 4,78 & 6,19 & 3,47 & 4,38 \\
\hline & & & 300,00 & 300,00 & 300,00 & 200,00 \\
\hline Kerangany & & & & &
\end{tabular}

Keterangan: * : Tumbuhan yang dimakan bekantan

Dari 20 jenis tumbuhan yang terdapat di Resort Semangit kawasan TNDS, pada tingkat pohon terdapat 6 jenis tumbuhan dominan yang 5 jenis diantaranya merupakan pakan bekantan yaitu; Kawi (S. balangeran), (113,97), 
Putat (B. acutangula) (27,83) dan Rengas (Gluta renghas) (17,57), Sikup (G. celebica) $(16,36)$ dan Kayu Tahun (Carallia sp.) (15, 37). Selain INP nilai dari indeks keanekaragaman dan kelimpahan jenis juga dihitung untuk melihat apakah sumber pakan bekantan di lokasi penelitian terdapat dalam jumlah yang cukup banyak. Suatu komunitas dikatakan memiliki keanekaragaman jenis yang tinggi jika komunitas disusun oleh banyak spesies. Sebaliknya, suatu komunitas dikatakan memiliki keanekaragaman jenis yang rendah jika komunitas itu disusun oleh sedikit spesies dan jika hanya sedikit yang dominan (Indriyanto, 2006).

Berdasarkan hasil analisis data pada tabel 5 didapat nilai indeks keanekaragaman jenis tumbuhan pakan bekantan dari tingkat semai sampai tingkat pohon, keanekaragaman tertinggi terdapat pada tinggat tiang $(\overline{\mathrm{H}}$ $=0,82)$, kemudian tingkat pancang $(\overline{\mathrm{H}}=$ $0,77)$, tingkat pohon $(\overline{\mathrm{H}}=0,67)$, tingkat semai $(\overline{\mathrm{H}}=0.61)$, keriteria dalam menentukan nilai keanekaragaman jenis, yaitu apabila $\overline{\mathrm{H}}$ mendekati 1 (satu) keanekaragaman jenis pada kawasan itu tergolong tinggi. Berdasarkan analisis data indeks keanekaragaman jenis tumbuhan pakan bekantan (Nasalis larvatus) di Resort Semangit kawasan TNDS pada tingkat pohon, tiang, pancang dan semai tergolong dalam kategori yang rendah (Odum, 1993).

Nilai indeks kelimpahan jenis (e) berperan untuk mengetahui pemerataan pembagian individu diantara jenis-jenis yang ada dalam suatu habitat. Menurut Odum (1993), nilai indeks kelimpahan jenis berkisar antara 0-1, jika e lebih dari 1 (e>1) maka seluruh jenis yang ada memiliki kelimpahan yang sama atau merata sedangkan jika nilai e kurang dari 1 (e<1) maka kelimpahan seluruh jenis tidak merata. Dari hasil rekapitulasi kelimpahan jenis tumbuhan pakan bekantan pada setiap tingkat pertumbuhan dapat dikatakan pada tingkat pohon, tiang, pancang dan semai memiliki kelimpahan jenis tidak merata.

Tabel 4. Jenis dan Kelimpahan Tumbuhan Pakan Bekantan (Nasalis larvatus) di Resort Semangit Kawasan Taman Nasional Danau Sentarum (Table 4. The Kinds and The Abundance Plants The Proboscis Monkey Food In The Resort Semangit National Park Lake Sentarum)

\begin{tabular}{llllllrlll}
\hline \multirow{2}{*}{ No } & \multirow{2}{*}{ Nama Lokal } & \multicolumn{3}{c}{$\overline{\mathbf{H}}$} & \multicolumn{3}{c}{$\mathbf{E}$} \\
\cline { 3 - 9 } & Se & $\mathbf{P a}$ & $\mathbf{T i}$ & $\mathbf{P o}$ & $\mathbf{S e}$ & $\mathbf{P a}$ & $\mathbf{T i}$ & $\mathbf{P o}$ \\
\hline 1. & Kayu Tahun & 0,08 & 0,09 & 0,11 & 0,08 & 0,07 & 0,10 & 0,09 & 0,09 \\
2. & Kawi & 0,13 & 0,15 & 0,15 & 0,14 & 0,10 & 0,17 & 0,13 & 0,16 \\
3. & Kebesi & 0,04 & 0,07 & 0,09 & 0,04 & 0,03 & 0,08 & 0,08 & 0,05 \\
4. & Mentangis & 0,03 & 0,09 & 0,08 & 0,05 & 0,03 & 0,10 & 0,07 & 0,06 \\
5. & Putat & 0,07 & 0,12 & 0,08 & 0,11 & 0,06 & 0,14 & 0,07 & 0,12 \\
6. & Rengas & 0,10 & 0,06 & 0,09 & 0,09 & 0,08 & 0,06 & 0,07 & 0,10 \\
7. & Sikup & 0,05 & 0,08 & 0,11 & 0,08 & 0,04 & 0,09 & 0,09 & 0,09 \\
8. & Temirit & 0,08 & 0,07 & 0,06 & 0,05 & 0,06 & 0,08 & 0,05 & 0,05 \\
\hline & Jumlah & $\mathbf{0 , 6 1}$ & $\mathbf{0 , 7 7}$ & $\mathbf{0 , 8 2}$ & $\mathbf{0 . 6 7}$ & $\mathbf{0 , 5 0}$ & $\mathbf{0 , 8 5}$ & $\mathbf{0 , 6 8}$ & $\mathbf{0 , 7 5}$ \\
\hline
\end{tabular}

Keterangan: Se: Semai; Pa: Pancang; Ti: Tiang; Po: Pohon 
8 jenis tumbuhan yang menjadi sumber pakan bekantan di Resort Semangit kawasan TNDS tersebut yaitu, Kawi ( $S$. balangeran), Kebesi

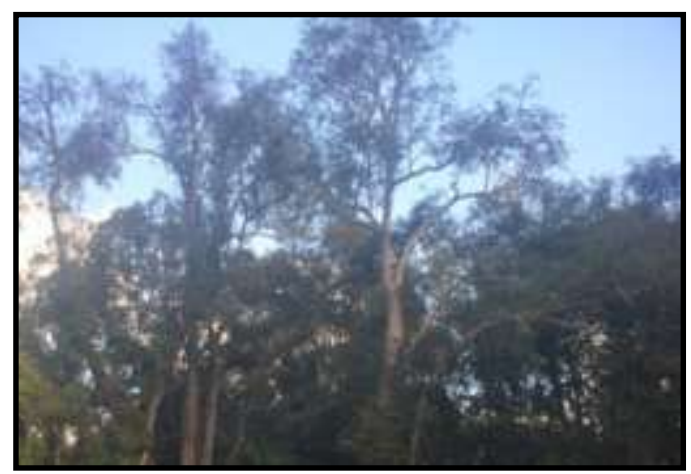

Gambar 1. Pohon Kawi (Shorea balangeran)

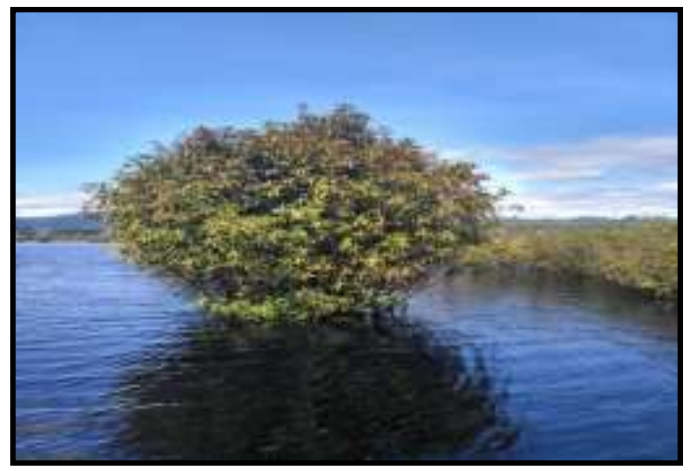

Gambar 3. Pohon Putat (Barringtonia acutangula)

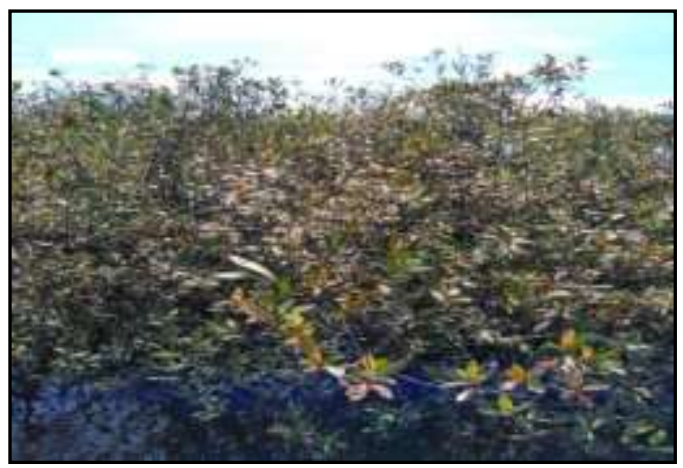

Gambar 5. Pohon Temirit (Timonius flavescens)
(M. edule), Putat (B. acutangula), Sikup (G. celebica), Temirit (T. flavescens) Kayu Tahun (Carallia sp), Mentangis (I.mentangis) dan Rengas (G. renghas).

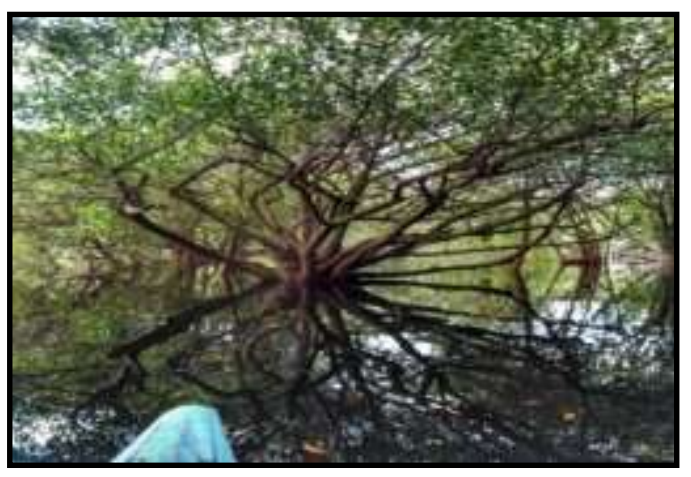

Gambar 2. Pohon Kebesi (Memecylon edule)

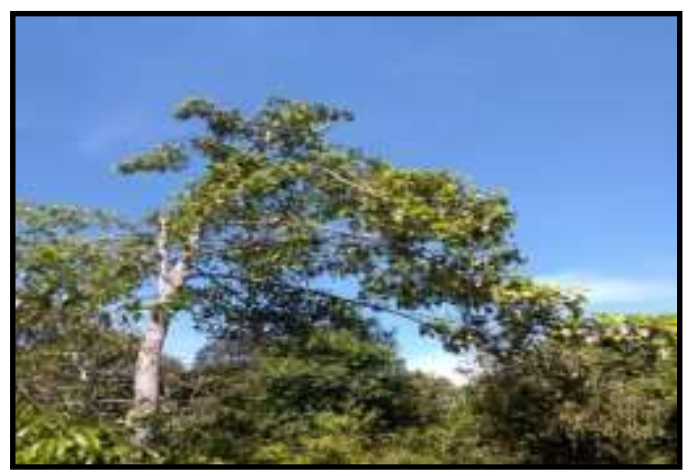

Gambar 4. Pohon Sikup (Garcinia celebica)

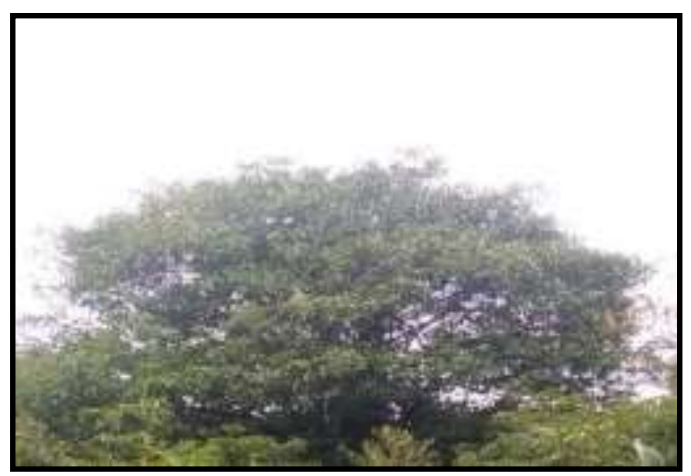

Gambar 6. Pohon Kayu Tahun (Carallia sp) 


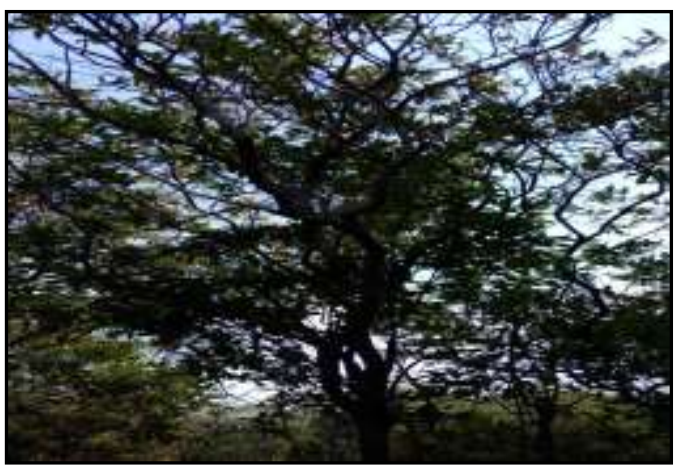

Gambar 7. Pohon Mentangis (Ixora mentangis)

\section{SIMPULAN DAN SARAN}

Berdasarkan pengamatan ditemukan 20 jenis tumbuhan dan 8 jenis diantaranya menjadi pakan bekantan di resort semangit kawasan TNDS. Nilai keragaman jenis tertinggi pada tingkat pohon dan tiang yaitu $S$. balangeran. Nilai kelimpahan jenis dari 8 jenis tumbuhan yang dimakan bekantan indeks kelimpahan jenis tertinggi yaitu $S$. Balangeran, kelimpahan jenis ini dipengaruhi oleh jumlah jenis tumbuhan tersebut yang ditemukan diseluruh petak penelitian.

Berdasarkan hasil analisis data didapatkan nilai indeks keanekaragaman jenis tumbuhan pakan bekantan dari tingkat semai sampai tingkat pohon, keanekaragaman tertinggi terdapat pada tinggat tiang $(\overline{\mathrm{H}}$ $=0,82)$, kemudian tingkat pancang $(\overline{\mathrm{H}}=$ $0,77)$, tingkat pohon $(\overline{\mathrm{H}}=0,67)$, tingkat semai $(\overline{\mathrm{H}}=0.61)$. Dari hasil rekapitulasi kelimpahan jenis tumbuhan pakan bekantan pada setiap tingkat pertumbuhan dapat dikatakan pada tingkat pohon, tiang, pancang dansemai memiliki kelimpahan jenis tidak merata.

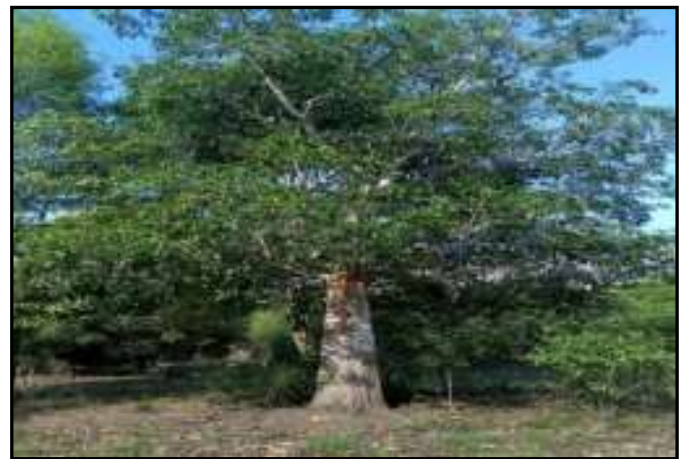

Gambar 8. Pohon Rengas (Gluta renghas)

Dari hasil analisis vegetasi diperoleh bahwa pertumbuhan pada tingkat tiang memiliki nilai keanekaragaman dan kelimpahan jenis yang tinggi, maka dari itu perlu adanya upaya penanganan khusus seperti meningkatkan peran kelembagaan pengelolaan kawasan hutan yang terkait dan jasa lingkungan agar ketersediaan pakan bekantan di kawasan tersebut tetap terjaga. Harapannya dengan demikian beberapa tahun yang akan datang tingkat keanekaragaman dan kelimpahan jenis pada tingkat pohon juga akan meningkat.

\section{DAFTAR PUSTAKA}

Atmoko T dan Sidiyasa K. 2015. Karakteristik Vegetasi Habitat Pakan Bekantan (Nasalis larvatus Wurmb) Di Delta Mahakam, Kalimantan Timur. Jurnal Penelitian Hutan dan Konservasi Alam 5(4): 307-316.

Bismark M. 2009. Biologi Konservasi Bekantan (Nasalis larvatus). Pusat Penelitian Dan Pengembangan Hutan dan Konservasi Alam. Bogor.

[Dephut] Departemen Kehutanan. 1990. Undang-undang Nomor 5 Tahun 
1990 Tentang Konservasi Sumberdaya Alam Hayati dan Ekosistemnya. Dephut. Jakarta.

Hanggari ES. 2008. Identifikasi Vegetasi Di Koridor Sungai Siak dan Peranannya Dalam Penenrapan Metode Bioengineering. Jurnal Sains dan Teknologi Indonesia 10(2): 112118.

Indriyanto, 2006. Ekologi Hutan. Jakarta: Penerbit PT Bumi Aksara.

Lailati M. 2017. Karakteristik Morfologi Dan Anatomi Daun Genus Gracia Dataran Tinggi. PROS SEM NAS MASY BIODIV INDON 3(3): 407-411.

Murti FS. 2010. Etnofarmakologi dan Pemakaian Tanaman Obat Suku Dayak Tunjung Di Kalimantan Barat. Media Litbang Kesehatan 20(3): 104-112.

Odum, E.P. 1993. Dasar-dasar Ekologi. Terjemahan Tjahjono Samingan. Edisi Ketiga. Yogyakarta: Gadjah Mada University Press.

Syukur M. 2016. Habitat Pohon Putat (Barringtonia acutangula) Pada Kawasan Berhutan Sungai Jemelak Kabupaten Sintang. PIPER 12(23).

Usha M, Appavoo RM, Immanuel G. 2010. Ixora L. - An Overview. Europan Journal of Pharmaceutical and $M$ Edical Research 3(2): 146-154.

Widodo 2015. Karakteristik Memecylon sp. (Melastomataceae) dari Gunung Nglanggeran, Gunungkidul. PROS SEM NAS MASY BIODIV INDON 1(5): 969973.
Zainudin dan Rezeki A. 2016. Aktivitas Makan dan Jenis Pakan Bekantan (Nasalis larvatus) Di Pulau Bakut Kabupaten Barito Kuala. Prosiding Seminar Nasional Lahan Basah Jilid 1: 99-104. 